\title{
Flashcard Video in Teaching English Vocabularies Through Online Class During Pandemic Era
}

\author{
Roma Ayuni A. Loebis ${ }^{1}$, Wan Syaifuddin ${ }^{2}$ \\ \{roma@usu.ac.id\} \\ Faculty of Cultural Science, Universitas Sumatera Utara
}

\begin{abstract}
The present of Corona Virus Disease 2019 (Covid-19) has brought many changes in human lives, such as social behavior, economy sector and also education system. Realizing that the curve of this pandemic is still raising up in most parts of Indonesia, the Minister of Education and Culture has declared to change face-to-face class into on-line class program after it is announced that the academic year started on July 13, 2020. This condition impacts the English language teaching process, as teaching foreign language is most effective done in class where students can be actively involved in the learning process such as listening and speaking. The purpose if this research is to find out the effectiveness of transforming flash card into video form in learning vocabularies for students at 5th grade Sekolah Dasar Negeri (SDN) 10540 Namo Linting Senembah Tanjung Muda (STM) Hulu. The population of this research are 20 students at 5 th grade who are sent video by the English teacher. After two week they will be given oral task. The result shown the enhancement $45 \%$ at the first cycle, 55\% at the second cycle and $90 \%$ at the third cycle. It can be concluded that flash card in video form is adequate in fulfilling the English teaching model during pandemic era. Students' achievement in performing vocabularies prove that this model worth- applied in online class model.
\end{abstract}

Keywords: Flash card video, online class, pandemic era

\section{Introduction}

The presence of Covid-19 will directly and permanently change education in the future, seeing that we must be able to adapt to working and studying online for any kind of reasons and situations. Teacher should make extra effort to support education system. Students continue their education through online learning and via video calls with their teachers. This model is currently best alternatives as keeping schools open poses a safety risk for students. Nevertheless, students reported the home-learning program to be even more stressful than regular classroom. This is due to the inadequate stimulus that the student receives through the computer or cellular phone.

One of the subjects at 5th grade of SDN 105401 Namo Linting STM Hulu is English, it is become the problem for the teacher as technology is sometimes isolating. Students' interactions are limited and dissimilar to the kind of ways that they will be required to use English in class. The purpose of this analysis tried to propose the new form of flash card. It is formed into video so it can be easily shared to the students through cellular phone. Basically, online class is common at the higher education level such as at the university. As [1] when comparing the 
effectiveness of classroom and online learning found that online environment may be more challenging in research method class. But on the lower lever, especially in primary school this learning process might cause a certain problem especially in learning English. [2] said the challenge and constraints experienced by the student in primary school are limited communication and socializing among students. As for the teacher, it is hard to give feedback directly to the students though online. Overseas, [3] has already proposed a computer-assisted language learning (CALL) program as current trend in online language learning which could be applied during this pandemic situation.

In learning language, vocabularies play an important role. Vocabularies are all words in one language, which is acquired, comprehended and used by a speaker in speaking, listening, reading and writing. As [4] stated that vocabularies are collected words of a language and convey meaning when we used that language. [5] conveyed that vocabulary learning is central to language acquisition, whether the language is first, second, or foreign. That is why, vocabulaty became the prority to be taught at the early age. Students of SDN 105401 Namo Linting STM Hulu learn English since the 3rd grade. But early observation found that students at the 5 th grade still have problems in vocabulary.

Lack of vocabulary will hinder students in composing sentences. Compatible vocabulary can be gained with suitable method and proper technique. External factors which influenced youngster in learning English is learning material, learning media and social interaction. As [6] said that language teaching method is a coherent set of links between actions and thoughts in language teaching. The actions are the technique, and the thoughts are the principles. One of proportional material that should be given to children at primary school is vocabularies with pictures associated.

Flashcard is one of various media which suitable in learning new word because it contains picture with text. As [7] flashcard is a useful media to be used to enrich kindergarten student's vocabularies either using pictures or [8] alphabet method technique. Furthermore [9] brain responds to visual fast, better than text or any other kind of learning materials. Normally teacher will hold up and show the card in front if the student and say the new word which connected to the picture. Due to the Covid-19 pandemic, the situation will not be the same. Online class forces teacher to use more comprehended way, such as using video. [10] Teachers are challenged to use advanced technology in utilizing the flash card in video form as [11] video is available to be watched repeatedly That is why this research tried to propose flashcard video which contain flashcard with more varieties in form.

\section{Research Methods}

This research is a descriptive qualitative research [12] which describe the use of flashcard video in teaching English vocabularies .Population in this research are 5th grade students of SDN 105401 Namo Linting STM Hulu which consist of 20 students at 10-11 years old. This government primary school lies in Namo Linting village at Sinembah Tanjung Muda (STM) Hulu, Deli Serdang Regency. This analysis includes the classroom action research which covers four steps: preparation, implementation, conclusion and report. The purpose of classroom action research [13] is upgrading the quality of teaching process, resolving teaching learning problem and upgrading professionalism, and growing academic culture. The data are the numbers of English vocabularies the students were able to remember after they are given two flash card 
video consist of ten colors and ten animals. Data are collected through observation, test, documentation and interview.

The observation and analysis started from 21 July 2020 until 12 August 2020. It was conducted in three cycles. The first cycle was on 28 July 2020, the second cycle was on the 11 August 2020 and the third cycle was on 18 August 2020 .The flash card video was shared by the teacher to students through what apps (WA) on the 21 July 2020. It consists of 10 vocabularies of animals and 10 vocabularies of colours. At the second and the fourth week, the teacher made a video call and gave a test by showing flash card to the students and they answered based on the picture shown.

\section{Results and Discussion}

On the 21 July 2020, the teacher sends flashcard video which consist of ten pictures of animals (cat, tiger, cow, fish, rabbit, bird, elephant, bear, butterfly, ant). In the first cycle, they were tested by the teacher. On 4 August 2020, students were given ten picture contains ten colors (blue, white, green ,yellow, pink, purple, black, brown, red). In the second cycle, they were tested again by the teacher. In the third cycle, they were tested both about animals and colors by video call and interviewed about the flashcard video.

\section{Result}

Table1. Names and numbers of vocabularies can be answered

\begin{tabular}{|c|c|c|c|c|}
\hline No. & Student's name & Cycle 1 & Cycle 2 & Cycle 3 \\
\hline 1. & PS & 6 & 6 & 7 \\
\hline 2. & AA & 4 & 6 & 8 \\
\hline 3. & BN & 4 & 5 & 9 \\
\hline 4. & CG & 8 & 7 & 10 \\
\hline 5. & RA & 7 & 7 & 8 \\
\hline 6. & Y & 7 & 5 & 9 \\
\hline 7. & AG & 5 & 7 & 8 \\
\hline 8. & AE & 7 & 8 & 9 \\
\hline 9. & C br S & 8 & 8 & 10 \\
\hline 10 & DR & 6 & 8 & 8 \\
\hline 11. & DB & 7 & 7 & 7 \\
\hline 12. & EPT & 5 & 5 & 8 \\
\hline 13. & E br T & 6 & 4 & 7 \\
\hline 14. & GR & 6 & 7 & 10 \\
\hline 15. & IR & 5 & 6 & 9 \\
\hline 16. & IU & 7 & 7 & 10 \\
\hline 17. & KD & 8 & 8 & 10 \\
\hline 18. & MCD & 7 & 8 & 9 \\
\hline 19. & OR & 4 & 9 & 10 \\
\hline 20. & FYS & 5 & 5 & 8 \\
\hline
\end{tabular}

Indicator of student's achievement and the effectiveness of this research is formulated as follow:

8-10 words $=$ Excellent

$5-7$ words $=$ Good

$1-4=$ Poor 
with the criteria that students able to mention the name of animal and kind of colours which shown by the teacher.

Table2. The vocabularies mastery of the students

\begin{tabular}{llll}
\hline Aspect & Cycle 1 & Cycle 2 & Cycle 3 \\
\hline Theme & Animals & Colours & Animal and Colours \\
Observation & Test & Test & Test and interview \\
Result & $45 \%$ able & $55 \%$ able & $90 \%$ able to answer \\
& to answer & to answer & more than 7 words \\
& more than & more than correctly & \\
& 7 words & 7 words & \\
& correctly & correctly & \\
& & & \\
\hline
\end{tabular}

From Tables above can be seen that the progress and the improvement of the students in learning and understanding English vocabularies by watching flash and video. In the first cycle, 3 students are able to answer correctly 4 kinds of animal (Poor), 14 students are correctly answer 5 to 7 kinds of animal (Good) and 3 students are able to answer correctly 8-9 kinds of animal (Excellent). In the second cycle, only 1 student is able to answer 4 kinds of color (Poor), 13 students are able to answer correctly 5-7 kinds of colors (Good) and 6 students are able to answer correctly 8-9 kinds of color (Excellent). In the third cycle, only 3 students are able to answer correctly 5-7 kinds of animal and color (Good) and 17 students are able to answer correctly 810 kinds of animal and color (Excellent)

Students showed their significance progress in the third cycle. After tested, they were interviewed by the teacher about the flash card video. The reply was enthusiasm and happiness. Repetition in watching the video (visual) ease them to memorize the vocabularies. More over song and sounds (auditory) support them in learning happily from home.

The improvement of student's ability in memorizing English vocabularies after watching flash card video can be shown on this figure of student's result as follow:

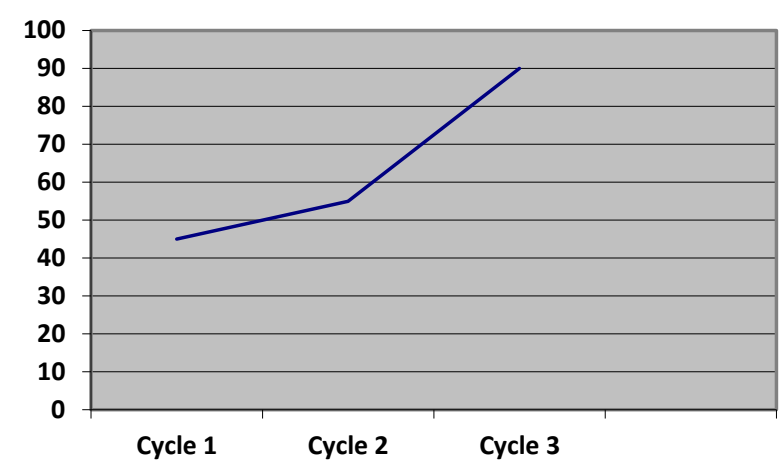

The description above showed that student's ability in learning English vocabularies by watching flash card videos improved with the satisfactory. 


\section{Conclusion}

From analysis above can be concluded that flashcard video plays great role as a media in teaching English vocabularies during online class in pandemic era. Normally flashcard are just cards handed out and shown by the teacher in front of the class, but flashcard video is more enjoyable because the students can play the video anytime, they like. As repetition is critical to most type of learning. Student's ability in learning vocabularies were improved by using video flashcard from cycle to cycle. This was proved by the percentage of students' achievement in answering questions given by the teacher.

At the first cycle it was $45 \%$, at the second cycle it was $55 \%$ and the third cycle it was $90 \%$.As repetition is critical to most type of learning. Based on this data, it can be concluded that video flash card is a suitable media to be used in online class model. This model has only been applied to one population and might need some reconstruction or readjustment if applied in other school.

\section{Acknowledgement}

This research was supported by Universitas Sumatera Utara under contract of Research Implementation Talenta USU, number: 181/UN5.2.3.1/PPM/SPP-TALENTA USU/2020 dated 28 April 2020

\section{References}

[1] AY.Ni, Comparing The Effectiveness of Classroom and Online Learning. Journal of Public Affais Education. Vol. 19-2013-Issue 2. Page 199-215. Published online 18 April 2018

[2] A. Purwanto et.al. Impact of The Covid-19 Pandemic on Online Home Learning-An Explorative Study of Primary Schools in Indonesia. Journal Education, Phsycology and Counseling. Vol. 2 No.1.2020

[3] Blake, Robert. Current Trends in Online Language Learning. Annual Review of Applied Linguistic. 31: 19-35. March 2011

[4] Suyanto dan Kasihani, K.E. English for Young Learners. Jakarta. Bumi Aksara. 2008

[5] Asyiah, D.N.The Vocabulary Teaching and Vocabulaary Learning: Perception, Strategies and Influences on Students'Vocabulary Mastery. Journal Lingua Scientia. Vol. 9 No. 2. 2017

[6] Larsen, Freeman D., Techniques and Principles in Language Teaching. Second Edition. Oxford: Oxford University. 2000

[7] Sholihah, U. Upaya Meningkatkan Keterampilan Berbicara Anak melalui Media Kartu Bergambar pada Anak Kelompok A di TK Islam Mardisim Surakarta TA. 2014/2015. Universitas Muhamadiyah Surakarta. 2015

[8] Parlindungan, F. Meningkatkan Kemampuan Penguasaan Kosakata Bahasa Inggris Anak Usia Dini dengan Menggunakan Alphabet Method. Thesis. UNISMA. 2011

[9] Iskandar, Joni. Meningkatkan Penguasaan Kosakata melaui Flashcard dalam Pembelajaran Bahasa Inggris di Sekolah Dasar. Jurnal Keislaman Terateks. Vo. 4, No.1 . Oktober 2019

[10] Hadijah, Siti, Teaching by using Video: Ways to Make It More Meaningful in EFL Classroom, Proceeding of ISELT FBS Universitas Negeri Padang, Vol.4, No. 2. 2016

[11] Purnaningsih, Pari, Strategi Pemanfaatan Media Audio Visual untuk Peningkatan Hasil Belajar Bahasa Inggris, Jurnal Informatika Universitas Pamulang. Vol.2. 2017

[12] M. B. and A. M. H. Miles, Qualitative Data Analysis: A Method Source Book. London, United Kingdom: SAGE Publication, 2014.

[13] Arikunto, S. Penelitian Tindakan Kelas Cetakan ke-6. Jakarta. Bumi Aksara. 2008 